\title{
The Effectiveness of Hypnotherapy to Reduce Anxiety in Pre-Caesarean Section Women
}

\author{
Rizka Innayatun Mubarokah'), Hanung Prasetya'), \\ Supriyadi Hari Respati3,4) \\ 1)Masters Program in Public Health, Universitas Sebelas Maret \\ 2)School of Health Polytechnics, Ministry of Health Surakarta \\ 3)Department of Obstetrics and Gynecology, Dr. Moewardi General Hospital \\ 4)Faculty of Medicine, Universitas Sebelas Maret
}

\section{ABSTRACT}

Background: Anxiety felt by women before delivery with cesarean section can cause psychological problem, increase pain in surgery, increase analgesic needs, and prolong hospital treatment. Hypnotherapy has minimal side effects and is easy to do in reducing anxiety. The purpose of this study was to analyze the effect of hypnotherapy in reducing anxiety in women with pre-cesarean section.

Subjects and Method: This was a randomized controlled trial study conducted at in Karanganyar Hospital, and PKU Muhammadiyah Hospital, Karanganyar, Central Java, from July to August 2019. A sample of 60 women was selected for this study by purposive sampling. 30 subjects of the treatment group received hypnotherapy intervention and 30 subjects of the control group received standard care. The dependent variable was anxiety. The independent variable was hypnotherapy. Anxiety was tested by the Hamilton Rating Scale for Anxiety questionnaire. Hypno- therapy was done using hypnosis recording/ audio. The data were analyzed by independent $t$ test.

Results: Mean of anxiety after hypnotherapy (mean $=14.17 ; \mathrm{SD}=4.36$ ) was lower than control group (mean = 19.93; $\mathrm{SD}=6.02)$, effect size $=$ 1.09 , and is statistically significant $(\mathrm{p}<0.001)$.

Conclusion: Hypnotherapy is effective in reducing anxiety in women before cesarean section.

Keywords: anxiety, hypnotherapy, cesarean section

\section{Correspondence:}

Rizka Innayatun Mubarokah. Masters Program in Public Health, Universitas Sebelas Maret. Jl. Ir. Sutami 36 A, Surakarta 57126, Central Java. Email: rizka.inn@gmail.com. Mobile: 082240337404

\section{Cite this as:}

Mubarokah RI, Prasetya H, Respati SH (2020). The Effectiveness of Hypnotherapy to Reduce Anxiety in PreCaesarean Section Women. J Matern Child Health. 5(1): 13-17. https://doi.org/10.26911/thejmch.2020.05.01.02.

(c) (i) (2) Journal of Maternal and Child Health is licensed under a Creative Commons EY NC SA Attribution-Non Commercial-Share Alike 4.0 International License.

\footnotetext{
BACKGROUND

Nearly one in three women get a cesarean section in developed countries, therefore this operation is the most common type of surgery performed (Hepp et al., 2018).

Although some cases of cesarean section are planned, most patients are afraid to face this procedure which is very significantly related to the level of stress or anxiety for patients (Hepp et al., 2018; Xu et
}

\section{al., 2017; Schantz et al., 2016).}

Caesarean section is associated with adverse psychological consequences for the mother, including porpartum depression (Xu et al., 2017). The psychological response that often occurs in patients undergoing surgery is anxiety. In addition to patients who think about conditions in themselves, they also think about conditions in their babies (Sriningsih and Afriani, 2014). 
Feelings of anxiety and fear in the face of childbirth are factors that can cause physical and physical tension that will be manifested in the muscles associated with labor (Imannura et al., 2016). Anxiety is a mental disorder that most often occurs. The prevalence of anxiety disorders was reported at $31 \%$. Unfortunately, this anxiety disorder is very underdiagnosed and poorly treated (Katzman et al., 2014). Anxiety is also associated with increased plasma catecholamine levels and electrolyte imbalance (Sahin et al., 2016).

Childbirth, caesarean birth, and anesthesia can produce anxiety in women. Maternal anxiety has a positive relationship with a higher risk in newborns such as premature birth and low birth west body (Ding et al., 2014). One of the anxiety effects is the lack of exclusive breastfeeding (Field, 2017). There is a positive direct relationship between anxiety and labor pain (Nisa et al., 2018).

Alladin (2016) states that any comprehensive therapy must include both conscious and unconscious therapies such as behavioral therapy, cognitive therapy, psychodynamic psychotherapy, therapy mindfulness and others in the treatment of anxiety disorders.

The key to overcoming anxiety, depression or stress is to adapt to want to change the situation that is being experienced if the coping mechanism is successful then the person will easily adapt to the situation that is felt (Setyadi et al., 2016).

Hypnosis/hypnotherapy receives less empirical attention, but the evidence suggests that it is a very effective treatment method for anxiety and disorders related to anxiety (Daitch, 2018). Hypnotherapy is scientific knowledge and has also been recognized by WHO as a safe way of therapy (Prasetya et al., 2018).

Based on the description above that pre-delivery mother with cesarean section experience anxiety and given the limited pharmacological intervention options for predelivery mothers, the need for low-risk alternatives is needed to approach positively to influence anxiety and stress that arise. In this case, the positive effect of hypnotherapy on anxiety is one of the treatment approaches chosen by authors.

\section{SUBJECTS AND METHOD}

\section{Study Design}

This study is an experimental study using a Randomized Controlled Trial (RCT). It was conducted at Karanganyar General Hospital and the PKU Muhammadiyah Karanganyar Hospital, Karanganyar, Central Java, from July to August 2019.

\section{Population and Sample}

The population in this study consisted of all women giving birth at the Karanganyar Hopital and Muhammadiyah Karanganyar Hospital, Karanganyar, Central Java, from July to August 2019. A sample of 60 women with pre-cesarean was selected by purposive sampling, divided into two groups.

Inclusion criteria in this study were recorded as a maternity patient with preoperative cesarean section, can communicate in Indonesian, have the ability to hear within normal limits, have the ability to attend hypnotherapy sessions, are willing to take part in experiments that will be given, and can read and write. Exclusion criteria in this study were preoperative maternity patients but with the emergence or complications of other diseases that require immediate cesarean section (CITO), have obstacles in communication, have psychiatric disorders that interfere with the process of hypnotherapy.

\section{Study Variables}

The dependent variable in this study is hypnotherapy. The independent variable is women's anxiety ahead of cesarean section.

4. Operational Definition of Variables Anxiety was defined as a mental state of a 
pregnant women whose concerns to their pregnancy. The measurement scale was continous. Hypnotherapy intervention was defined as the provision of suggestions to mothers in trance/hypnosis conditions, the suggestions given contain advice, invitations, the order is intended to reduce the level of anxiety in maternal preoperative cesarean section. Suggestions are given by authors using suggestion recordings on $\mathrm{MP} 3$ s or cellular phones that have been prepared. Coding in this study is "Yes" for the treatment group and "No" for the control group, so the scale of the data in this group is the nominal dichotomy included in the categorical data.

\section{Study Instruments}

Anxiety pre-cesarean patients used HRS-A (Hamilton Rating Scale for Anxiety) which consists of 14 groups of symptoms. Each symptom group was given a rating of $0-4$. Measurement of maternal anxiety was done twice on each respondent that was done before and after hypnotherapy in the action group and the control group. Categorizing the data was done based on the pure value of calculating the total score obtained. This study employed a study instrument in the form of an anxiety questionnaire using Hamilton Rating Scale for Anxiety (HRS-A) to measure anxiety in pre-cesarean patients. Hypnotherapy was conducted by played hypnotherapy audio suggestion/ recording using a headset from a cellular device or MP3.

\section{Data Analysis}

Mean difference of anxiety in pregnant women before and after the intervention were tested by independent $t$ test run on SPSS 25 program.

\section{Research Ethic}

This study used an informed consent sheet from the subjects, which is anonymous, and confidential. It has also obtained ethical clearance research from Research Ethics Committee in Dr. Moewardi Hospital, Surakarta, Central Java, with number: 846/ VII/ HREC/2019.

\section{RESULTS}

1. Univariate analysis

The univariate analysis description explained the general characteristics of the sample data of each variable including data on age, parity, education, and occupation. Univariate analysis can be seen in Table 1 and 2

Table 1. The characteristics of continuous data samples

\begin{tabular}{llllll}
\hline Group & n & Mean & SD & Min & Max \\
\hline Age (years) & 60 & 30.13 & 6.046 & 19 & 45 \\
Parity & 60 & 2.17 & 1.224 & 1 & 5 \\
\hline
\end{tabular}

\section{The result of bivariate analysis}

The bivariate analysis in this study used the independent $t$ test to test the mean difference between the independent and dependent variables. Test results about the different anxiety levels in the hypnotherapy intervention group and the standard care group are presented in Table 2.

\section{Table 2. The characteristics of categorical data samples}

\begin{tabular}{lcc} 
Variables & n & \% \\
\hline Education & & \\
ES & 14 & 23.3 \\
JHS & 4 & 6.7 \\
SHS & 31 & 51.7 \\
College & 11 & 18.3
\end{tabular}

\section{Employment}


Mubarokah et al. (jika lebih dari 1)/ The Effectiveness of Hypnotherapy to Reduce Anxiety

\begin{tabular}{lcc} 
House Wife & 27 & 45 \\
Laborer & 15 & 25 \\
Entrepreneur & 13 & 21.7 \\
Civil Servant & 5 & 8.3 \\
\hline
\end{tabular}

Table 3 showed that there was no difference in mean anxiety between the hypnotherapy group and non-hypnotherapy before the intervention, and it was statistically non-significant $(\mathrm{p}=0.892)$. These results indi cated that the randomization carried out in allocating into the hypnotherapy group and not hypnotherapy succeeded in making the two groups comparable in the initial anxiety level before the intervention.

Table 3. The results of the t-test mean differences in anxiety in the hypnotherapy group and non-hypnotherapy before the intervention

\begin{tabular}{lllll}
\hline Group & n & Mean & SD & p \\
\hline Hypnotherapy & 30 & 16.77 & 5.64 & 0.892 \\
Non Hypnotherapy & 30 & 16.97 & 5.75 & \\
\hline
\end{tabular}

Table 4 showed the mean anxiety in the hypnotherapy group (Mean=14.17; $\mathrm{SD}=4.36)$ lower than the non-hypnotherapy group (Mean=19.93; $\mathrm{SD}=6.02$ ) and the difference was statistically significant ( $\mathrm{p}<0.001)$.
These findings indicated that hypnotherapy was effective for reducing anxiety in patients with pre-cesarean section. These results came from the Randomized Controlled Trial (RCT).

Table 4. Mean differences of anxiety in the hypnotherapy and non-hypnotherapy groups after the intervention

\begin{tabular}{lllll}
\hline Group & n & Mean & SD & p \\
\hline Hypnotherapy & 30 & 14.17 & 4.36 & $<0.001$ \\
Non Hypnotherapy & 30 & 19.93 & 6.02 & \\
\hline
\end{tabular}

\section{Size Effect}

The effect of the use of hypnotherapy on anxiety reduction in pre cesarean patients known based on the calculation was equal to -1.09. Based on Cohen's standard effect size value 0.8-2.o has a high effect. Thus, the use of hypnotherapy has a high influence in reducing anxiety in patients with precesarean section.

\section{DISCUSSION}

The results of the study used an independent t test to determine the effect of hypnotherapy in the control group and the treatment group. Data Table 2.2 showed that patients who received intervention or patients who received hypnotherapy had lower average anxiety levels compared to the control group or the group that only got standard care.

This study can further strengthen the opinion that a program in the mind that has been instilled through affirmation or suggestion in a hypnotic state, can be a trigger for a change that was permanent (Beneditis, 2015). The hypnotic state began by focusing someone's attention, creating a relaxation response through induction and deepening techniques (Daitch, 2018).

The addition of hypnosis substantially increased the therapeutic outcome positively. The average patient who received cognitive behavior oriented hypnosis showed a greater improvement than at least $70 \%$ of patients who received non-hipnotic treatment 
(Alladin, 2016), Someone who was in a state of hypnosis can significantly improve brain function because that person can access the subconscious mind. So using hypnotherapy the behavior changes can be desired through the subconscious mind (Prasetya et al., 2018).

Kluft (2018) stated that there was a very unique therapeutic relationship in someone who was in a deep phase of hypnosis, they can change and move forward towards new insights incorporated in hypnotic suggestions that were considered by psychoanalytic insights. In the process of induction in someone who has been hypnotized, this pre induction can strengthen beliefs and expectations about what might happen when thinking, feeling, and doing something, thus increasing motivation to respond by involving his imagination in the suggestion given (Lynn et al., 2017).

In the influence of hypnosis, there was a strong inhibition in the cerebral cortex so that the power of analysis, identification and decision making on new stimulation was decreased, past experience cannot be utilized, so words that were suggestive would become a dominant force that would not be able to ignore. This explanation mean that in hypnosis conditions through suggestions that were actively given conditions and behavior in patients both psychic or physiological can be controlled, so that hypnotherapy was able to influence individual perceptions of anxiety so that hypnotherapy can reduce anxiety levels in patients with pre-cesarean section (Prasetya et al., 2018; Iserson, 2014).

Giving suggestions to someone created a sense of comfort, all the anxiety felt as if it turned into happiness in welcoming the baby. As a result, someone who was hypnotized felt comfortable and the level of anxiety in the patient can decrease just before the cesarean section.

Someone who felt comfortable because of hypnotherapy intervention would have better readiness in doing labor with cesarean section surgery, while in mothers who did not feel comfortable when getting standard care tend to experience feelings of anxiety in approaching Caesarean section. This was because they were more able to think positively by considering and overcoming problems that were felt optimally and following the positive suggestions that have been given.

\section{AUTHOR CONTRIBUTION}

Rizka Innayatun Mubarokah as the main author conducted the study intervention, wrote the manuscript, and examined the data. Hanung Prasetya created the hypnotherapy audio instruments. Supriyadi Hari Respati formulating study methods and suggested the materials for discussion.

\section{CONFLICT OF INTEREST}

There was no conflict of interest.

\section{FUNDING AND SPONSORSHIP}

This study was self-funded.

\section{ACKNOWLEDGEMENT}

Acknowledgments were conveyed by the authors to the director of the Karanganyar Hospital and PKU Muhammadiyah Karanganyar for allowing this study to be carried out. Thank you to all the health personnel for helping in data collection. Thank you to all the mothers with preoperative cesarean section who have been willing and cooperative to become the study subjects.

\section{REFERENCE}

Alladin A (2016). Cognitive hypnotherapy for accessing and healing emotional injuries for anxiety disorders cognitive hypnotherapy for accessing and healing emotional injuries for anxiety disorders. Am J Clin Hypn. 59(1): 24-46. https://doi.org/10.1080/o0029157.2016.1163662. 
Mubarokah et al. (jika lebih dari 1)/ The Effectiveness of Hypnotherapy to Reduce Anxiety

Benedittis GD (2015). Neutral mechanism of hypnosis and meditation. J Psychol 11(1): 10-16. https://doi.org/10.1016/j.jphysparis.2015.11.001

Daitch C (2018). Cognitive behavioral therapy, mindfulness, and hypnosis as treatment methods for generalized anxiety disorder cognitive behavioral therapy, mindfulness, and hypnosis as treatment methods for generalized anxiety disorder. Am J Clin Hyp, 61: 5769. https://doi.org/10.1080/00029157.2018 .1458594

Ding XX, Wu YL, Xu SJ, Zhu RP, Jia XM (2014). Maternal anxiety during pregnancy and adverse birth outcomes; a systematic review and meta-analysis of prospective cohort studies. J Affect Disord, 159: 103-109. https://doi. org/10.1016/j.jad.2014.02.027.

Field $T$ (2017). Infant behavior and development prenatal anxiety a review. Infant Behavior and Development. 49: 120-128. https://doi.org/10.1016/j.infbeh.2017.08.008

Hepp P, Hagenbeck C, Burghardt B, Jaeger B, Wolf OT, Fehm TM (2016). Measuring the course of anxiety in women giving birth by caesarean section: a prospective study. BMC Pregnancy Childbirth. 1-7. https: //doi. org/10.1186/s128840160906z

Imannura SP, Pamungkasari EP, Budihastuti UR (2016). The Effectiveness of Hypnobirthing in Reducing Anxiety Level During Delivery, 1(3): 200-204. J Matern Child Health https://doi.org/10.26911/thejmch.2016.01.03.08.

Iserson KV (2014). An hypnotic suggestion: review of hypnosis for clinical emergency care. J Emerg Med. 46 (4); 588596. https://doi.org/10.1016/j.jemermed.2013.09.024

Katzman MA, Bleau P, Blier P, Chokka P, Kjernisted K, Ameringen MV (2014).
Canadian clinical practice guidelines for the management of anxiety, posttraumatic stress and obsessive-compulsive disorders. BMC Psychiatry. 14(1):1-83. Doi: https://doi.org/10.1186/1471244X-14-S1-S1

Kluft RP (2018). Reconsidering hypnosis and psychoanalysis: toward creating a context for understanding reconsidering hypnosis and psychoanalysis: toward creating a context for understanding. Am J Clin Hypn. 60(3): 201-215. https: //doi.org/10.1080/00029157.2018.1400810.

Lynn SJ, Maxwell R, Green JP, Jay S (2017). The hypnotic induction in the broad scheme of hypnosis: A sociocognitive perspective. Am J Clin Hypn. 59; 363384. https://doi.org/10.1080/o0029157.2016.1233093

Nisa SMK, Respati SH, Murti B (2018). Psychosocial factors associated with anxiety and delivery pain. $J$ Matern Child Health. 3(1): 44-58. https://doi.org/10.26911/thejmch.2018.03.01. 05 .

Prasetya H, Murti B, Anantanyu S, Syamsulhadi M (2018). The effect of hypnosis on adherence to anti tuberculosis drugs using the health belief model. Int J Clin Exp Hypn. 66 (2): 211-227. https:// doi.org/10.1080/00207144.2018 1421361.

Sahin T, Ersel G, Sarac M, Sibel T (2016). Association between preoperative maternal anxiety and neonatal outcomes: a prospective. J Clin Anest. 33: 123126. https://doi. org/10.1016/j.jclinane.2016.03.022

Schantz, Clemente, Penh PC, Leang K, Rany $\mathrm{H}$ (2016). Factors associated with caesarean sections in factors associated with caesarean sections in Phnom Penh, Cambodia. J Hist Med. 24(48): 111-121. https://doi.org/10.1016/j.rh- 
Mubarokah et al. (jika lebih dari 1)/ The Effectiveness of Hypnotherapy to Reduce Anxiety

m.2016.11.009.

Setyadi AW, Murti B, Demartoto A (2015). The effect of hypnotherapy on depression, anxiety, and stress, in people living with HIV/AIDS, in "Friendship Plus" peer supporting group, in Kediri, East Java. J Health Promot Behav. 1(2): 99-108. https://doi.org.10.26911/thejhpb.2016.01.02.05.

Sriningsih I, Afriani D (2014). The level of anxiety of preoperative patients in cesarean section surgery in the Srikandi

room of Semarang City Hospital. Jurnal Keperawatan Maternitas. 2(2): 106-110. Retrived from https://www.google.com/url?sa=t\&sourse $=$ web\&rct $=$ j\&url=http://ppnijateng.org/wp-content/uploads/

Xu H, Ding Y, Ma Y, Xin X, Zhang D (2017). Cesarean section and risk of postpartum depression: A meta-analysis. J Psychosom Res. 97:118-126. https://doi.org/10.1016/j.jpsychores.2017.04.016 . 